Document downloaded from:

http://hdl.handle.net/10251/80964

This paper must be cited as:

Amoros Muñoz, I.; Moreno Trigos, MY.; Reyes-Sosa, MB.; Moreno-Mesonero, L.; Alonso Molina, JL. (2016). Prevalence of Cryptosporidium oocysts and Giardia cysts in raw and treated sewage sludges. Environmental Technology. 37(22):2898-2904. doi:10.1080/09593330.2016.1168486.

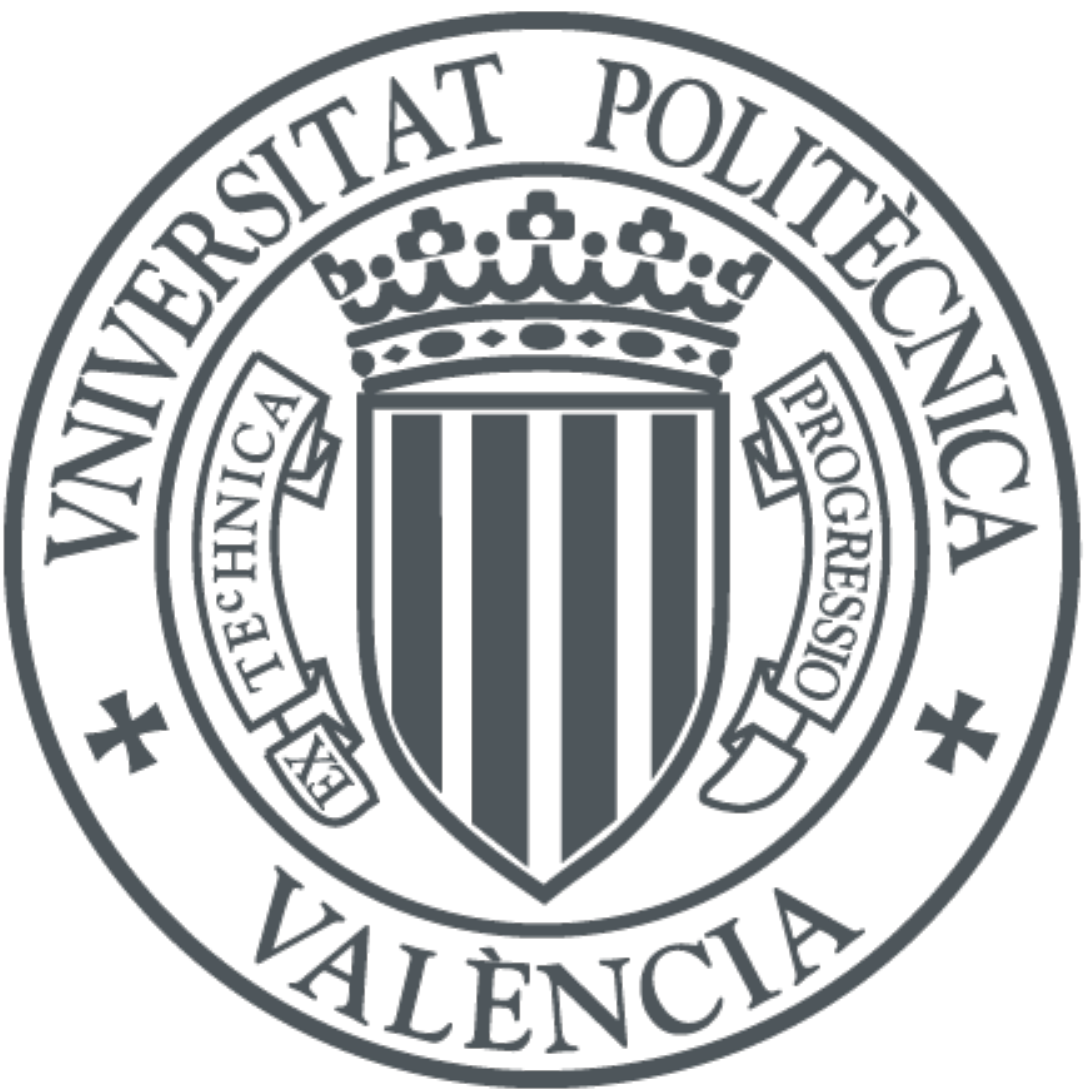

The final publication is available at

http://dx.doi.org/10.1080/09593330.2016.1168486

Copyright Taylor \& Francis

Additional Information 


\title{
Prevalence of Cryptosporidium oocysts and Giardia cysts in raw and treated sewage
}

\section{sludges}

Inmaculada Amorós ; Yolanda Moreno; Mariela Reyes; Laura Moreno-Mesonero and

Jose L. Alonso

${ }^{a}$ Instituto de Ingeniería del Agua y Medio Ambiente. Universitat Politècnica de València, Spain. Camino de Vera s/n, 46022 Valencia, Spain

\begin{abstract}
Treated sludge from wastewater treatment plants is commonly used in agriculture as fertilizers and to amend soils. The most significant health hazard for sewage sludge relates to the wide range of pathogenic microorganisms such as protozoa parasites. The objective of this study was to collect quantitative data on Cryptosporidium oocysts and Giardia cysts in the treated sludge in wastewater treatment facilities in Spain.

Sludge from five wastewater treatment plants (WWTPs) with different stabilization processes, has been analyzed for the presence of Cryptosporidium and Giardia in the raw sludge and after the sludge treatment. A composting plant (CP) has also been assessed.

After a sedimentation step, sludge samples were processed and (oo)cysts isolated by immunomagnetic separation (IMS) and detected by immunofluorescence assay (IFA). Results obtained in this study showed that Cryptosporidium oocysts and Giardia cysts were present in 26 of the 30 samples (86.6\%) of raw sludge samples. In treated sludge samples, (oo)cysts have been observed in all WWTP’s analyzed (25 samples) with different stabilisation treatment (83.3\%). Only in samples from composting plant no (oo)cysts were detected. This study provides evidence that (oo)cysts are present in sewage sludge-end products from wastewater treatment processes with the negative consequences for public health
\end{abstract}

Keywords: Cryptosporidium, Giardia, prevalence, sewage sludge, biosolids 


\section{Introduction}

Cryptosporidium and Giardia are infectious protozoan parasites capable of causing gastrointestinal illnesses in both animals and humans. An infected person can shed up to $3 \times 10^{9}$ oocysts [1] or up to $5 \times 10^{8}$ cysts over the course of infection.[2] In fact, these parasites are the most common food and waterborne protozoa that affect humans and a wide range of animals, which can shed large numbers of the transmissive stages of these enteropathogens, (oo)cysts, in their surroundings.[3-7] Livestock operations and irrigation with polluted water can lead to the contamination of soil and vegetables with zoonotic faecal pathogens, in which Giardia duodenalis cysts and Cryptosporidium parvum oocysts are included.[8-11] Cryptosporidium and Giardia (oo)cysts are environmental resistant stages, and can survive at different temperatures and conditions.[12]

Aerobic wastewater treatment plants use sludge activated sludge process to reduce water pollution and the presence of microorganisms. Many of these microorganisms are trapped in, or adsorbed to particulates and are concentrated in the sludge. For example, during the separation of solid material from wastewater in both primary (settling) and secondary treatments, numerous pathogens remain associated with particulates thus concentrating them in the sludge.[13-14] Therefore, sludge can contain many of these parasites.[15-18]

Sewage sludge is the solid, organic material which remains after wastewater is treated and discharged from a wastewater treatment plant. Sludge is treated to stabilize the organic matter and reduce the amount of human pathogens.[19] Several treatments can be employed to reduce the pathogen content in sewage sludge, such as heat-drying, addition of hydrated lime (calcium hydroxide) to increase $\mathrm{pH}$, composting, and biological digestion.[13] Biological digestion is the treatment method most frequently used to achieve stabilization, and involves decomposition of organic matter by microorganisms either in the presence of oxygen (aerobic digestion) or in its absence (anaerobic digestion).

Applications of sewage sludge-end products are an ecologically important means for the utilization of nitrogen and phosphorus. However, spreading sludge on agricultural lands, which has increased during the last years due to economic and environmental reasons,[20] facilitates circulation of Cryptosporidium and Giardia in the environment. It also contaminates shallow aquifers, potable waters [21] and food 
cropped from land, thus posing a threat to human and animal health. During rainfall, (oo)cysts may end in surface and groundwater.[3] The very low infective dose of these parasites also suggests a health risk for workers exposed to sewage.[22]

Various studies have identified high levels of Cryptosporidium oocysts and Giardia cysts in both treated and untreated sewage sludge. [17-20,23-27] However, information on the effectiveness of sludge treatments on the inactivation of Cryptosporidium and Giardia is incomplete.[20,28-30] Consequently, it is important to quantify the risks of contamination associated with this practice, which in turn requires accurate methods to quantify the levels of Cryptosporidium and Giardia in biosolids, such as sewage sludge.

Several methods have been described to enumerate Cryptosporidium oocysts and Giardia cysts in different biosolids. These methods include ECP (ether clarification procedure), [31] $\mathrm{NaCl}$ flotation and differential density centrifugation with percoll-

sucrose [32,33] and immunomagnetic separation (IMS) followed by immunofluorescence assay (IFA).[34-36,18] Recovery efficiencies associated with these methods have been determined by a number of researchers, but the results exhibit a considerable degree of variation.[37] A sedimentation step before immunomagnetic separation has been established by Massanet-Nicolau.[37] This method was used to recover stained cysts and oocysts (spiked organisms) from primary settled sewage sludge, anaerobically digested sewage sludge, and bovine manure.

The aim of this study was to determine the occurrence of Cryptosporidium oocysts and Giardia cysts in raw and treated sludge from five wastewater treatment plants and from a composting plant to evaluate the levels of (oo)cysts present after each stabilization treatment .

\section{Materials and Methods}

\section{Sludge samples and sampling sites}

A total of 60 sludge samples (30 raw sludge and 30 treated sludge) have been processed from five wastewater treatment plants (WWTP) located in Eastern Spain: (WWTP1 ,WWTP2, WWTP3 ,WWTP4, WWTP5), that served different population (between 20,000 and 200,000 equivalent inhabitants) with different sludge treatments (Table 1) and which also received both agricultural and industrial inputs. Moreover, five samples from a composting plant (CP), which received sludge from some WWTPs, have also 
been evaluated. In the case of the composting plant, dewatered sludge (raw) from different municipal sewage treatment plants is sent to the thermophilic composting process. Degradation occurs through longitudinal windrows (covered with a Gore cover). Ambient air is sucked through the piles during 10 days, where temperature is approximately $55^{\circ} \mathrm{C}$. The final product (from now on, referred to as compost) is stored for 30 days.

Samples were collected monthly over five samplings, from March to July in WWTP1, WWTP2 and WWTP3, and from September to January in WWTP4, WWTP5 and WWTP6. Each sample was transported to the laboratory, kept at $4^{\circ} \mathrm{C}$ and tested within the next $12 \mathrm{~h}$.

\section{Cysts and oocysts detection in sludge}

A reported method by Massanet-Nicolau [37] for sludge using a sedimentation step followed of inmunomagnetic separation has been used. One-gram samples of the sludge were deposited in 50-ml plastic centrifuge tubes (Corning). 25-ml volume of $0.1 \mathrm{M}$ phosphate-buffered saline (Sigma-Aldrich, St. Louis, MO) was added to the centrifuge tube containing the sludge sample and vortexed for $60 \mathrm{~s}$. Another $25 \mathrm{ml}$ of phosphatebuffered saline was then added to the sample, and the tube was inverted five times. The sample was left to stand for $60 \mathrm{~min}$ at room temperature, during which the heavier particles of debris settled at the bottom of the tube. At the end of the 60-min period, a 10-ml disposable pipette was used to transfer the top $45 \mathrm{ml}$ of liquid to a clean $50-\mathrm{ml}$ centrifuge tube. During this step, care was taken not to disturb the accumulated solids at the bottom of the tube. The $45 \mathrm{ml}$ of liquid was then brought to a final volume of $50 \mathrm{ml}$ with filtered deionized water and centrifuged for 5 min at $1,050 \times g$ (with no braking during the deceleration phase). The rest of the analytical procedure was based on the U.S. Environmental Protection Agency Method 1623.[34] The sample was then further purified by immunomagnetic separation. After centrifugation, the pellet was resuspended in $10 \mathrm{ml}$ of water in a Leighton tube, and immunomagnetic separation (IMS) was conducted using the commercially available GC Combo kit (InvitrogenDynal AS Oslo) according to the manufacturer's instructions. The final concentrate from the IMS was transferred onto the well of a slide and dried overnight at room temperature. The slide was labeled with fluorescent monoclonal antibodies fluorescein isothiocyanate (FITC) for Giardia and Cryptosporidium immunofluorescence assay 
(IFA), according to the manufacturer's protocol, (Meridian Diagnostics, Inc., Cincinnati, $\mathrm{OH})$.

Fifty microliters of (4,6-diamidino-2-phenylindole dihydrochloride) DAPI (Sigma-Aldrich, St. Louis, MO) solution $(0.4 \mathrm{mg} / \mathrm{ml}$ in PBS) were placed in each well of the slide and allowed to stand at room temperature for $15 \mathrm{~min}$; excess of DAPI solution was removed by washing the slides twice in PBS. Slides were placed under darkness, mounted and examined at $600 \mathrm{X}$ magnification using epifluorescence microscopy (Olympus BX 50, Tokyo, Japan). A blue filter (excitation, $480 \mathrm{~nm}$; emission, $520 \mathrm{~nm}$ ) was used to detect fluorescein isothiocyanate-conjugated MAblabeled (oo)cysts, and a UV filter block was used for DAPI (excitation, $350 \mathrm{~nm}$; emission , $450 \mathrm{~nm})$.

\section{Results}

The occurrence of (oo)cysts has been studied in sludge from wastewater treatment plants before and after different stabilization treatments.

Data showed (Table 2) that oocysts of Cryptosporidium and cysts of Giardia were present in 26 of the 30 raw sludge samples (86.6\%). The average concentration of Cryptosporidium was higher than Giardia's average in WWTP1, WWTP2, WWTP3 and WWTP4 and lower in the raw sludge arriving to Composting Plant (CP). In WWTP5 same average of oocysts than cysts was found.

In the treated sludges, (oo)cysts were detected in WWTP1, WWTP2, WWTP3, WWTP4, and WWTP5 (83.3\%). Only in the sludge from CP that was composted, no (oo)cysts were detected.

In WWTP2, WWTP4 (aerobic digestion) and WWTP5 (lime stabilization and heat drying) the average of oo(cysts) detected in treated sludge was higher than in sludge before treatment. In WWTP1 and WWTP3, the average of (oo)cysts was lower in the sludge after treatment (anaerobic digestion and lime stabilization respectively) but in some samples, (oo)cysts counts were higher in treated sludge than in mixture sludge before treatment, particularly in WWTP1 (Table 2). Maximum levels of Cryptosporidium of 498 oocysts/g and 248 cysts/g of Giardia have been found in WWTP1 during the sampling 1 (Table 2), although the average of (oo)cysts was lower in treated sludge than in raw sludge. Sludge from this WWTP is used in agriculture, 
which may pose a health risk. In the CP, counts of (oo)cysts after composting were 0 in all samplings (Table 2).

\section{Discussion}

The sedimentation step followed by IMS -IFA [37] used in this work has proven to be useful for simultaneous detection of Cryptosporidium oocysts and Giardia cysts in raw and treated sludge. Recovery efficiencies associated with this method were approximately 40 to $60 \%$ and were significantly greater than those associated with similar methods based on sucrose flotation $(P<0.001)$.[37] Other authors [35] also found high counts of Cryptosporidium oocysts, 70\%, using IMS and IFA after a spontaneous sedimentation. In contrast, Orlofsky et al. [36] obtained better results avoiding the sedimentation step.

In raw sludge samples, higher counts of Cryptosporidium oocysts than Giardia cysts have been detected (Table 2). Similar findings were reported in a study in Ireland.[27]

The different treatments used for sludge stabilisation in the studied WWTPs (Table 1) have not proven to be effective for total (oo)cysts elimination. Among the sludge treatments studied in this work, aerobic digestion and lime stabilisation showed higher average concentration of (oo)cysts in treated sludge than in raw sludge.

Furthermore, Cryptosporidium oocysts counts in treated sludge were higher than Giardia cysts' counts in WWTP1, WWTP2, WWTP3 and WWTP4. Only in WWTP5, higher counts of cysts than oocysts were found. Hence, Cryptosporidium oocysts appear to be more resistant to treatments compared to Giardia cysts.

Of the different disposal methods available for biosolids, composting presents certain advantages over more traditional methods, such as direct land application, incineration or burying in landfills. Composting is known to decrease the load of human pathogenic microorganisms potentially present in biosolids. It also yields an end product rich in organic matter and nutrients that can be used as a soil supplement for different environmental practices. In our study, only in composted sludge, no (oo)cysts were found. Other authors [38,39] agree that Giardia and Cryptosporidium are relatively sensitive to heat treatment and are rapidly reduced within thermophilic composting. In contrast, in a study about occurrence of pathogens in treated sludge,[40] Cryptosporidium oocysts were still detected in most compost samples. The inactivation 
of Giardia and Cryptosporidium (oo)cysts during composting of biosolids was monitored by Rimhanen-Finne et al. [20] and results showed that $44 \%$ and $37.5 \%$ of compost samples were positive for cysts and oocysts respectively after 10 weeks of composting.

Anaerobically digested biosolids have been reported to contain up to $10^{1}$ oocysts/g of Cryptosporidium and $10^{2}$ cysts/g Giardia. [15] In the dewatering processes, $50 \%$ percent of the pathogens were assumed to attach to sludge particulates. High Giardia cyst numbers $\left(10^{2}\right.$ cysts/g) following anaerobic digestion were reported in a study in Perth (Australia). [40] Other authors, [41,42] have also found Giardia cysts in both digested and undigested sludge, and there were no significant differences between their occurrence in raw and treated sludge, concluding that Giardia cysts did not appear to be reduced by anaerobic digestion. In our study, the anaerobically digested sludge from WWTP1 also contained up to $10^{2} / \mathrm{g}$ (oo)cysts. It is possible that during the sludge treatment, such as anaerobic digestion where temperature is generally more than $35^{\circ} \mathrm{C}$, (oo)cysts might lose viability and infectivity rapidly. In most of the studies, $[15,17,20]$ viability assessment of oo(cysts) is either not carried out or was inconclusive.

Regarding aerobic digestion, results obtained in our study in both WWTP2 and WWTP4, showed that the average of (oo)cysts present in sludge after stabilization were higher than in raw sludge. In a study about efficiency of a wastewater treatment plant for removal pathogens in Spain, [43] Giardia was detected in the sludge after aerobic digestion and no Cryptosporidium was detected; other authors [15] found higher reductions in Cryptosporidium (2.96 log) compared to Giardia's (1.40 log) during aerobic digestion of sludge.

In the present study, higher counts of Cryptosporidium oocysts than Giardia cysts have been detected in treated sludge from wastewater treatment plants, where sludge treatment was either lime stabilization or anaerobic or aerobic digestion. However, some authors [25] found that quicklime stabilization treatments reduced the load of both pathogens to non-detectable levels. Other studies, [29] have reported cysts of Giardia in sludge after lime stabilization, but no Cryptosporidium oocysts were detected. Similar findings reported in sewage sludge [31,44] have been explained by much higher relative incidence of giardiasis than cryptosporidiosis cases, that is, $300 \mathrm{vs.}$ 10, respectively, in communities served byWWTPs.[29] In a study in Poland [25] it was found that the mean concentration of Cryptosporidium oocysts in sewage sludge 
samples in two wastewater treatment plants was significantly lower than the concentration of Giardia cysts found in these samples. Giardia cysts are more frequently isolated in higher numbers throughout the year from wastewater and biosolids than Cryptosporidium oocysts, which showed seasonal variation. [45,46]

Limited information is available on the fate of protozoan pathogens in biosolids. Moreover, interpretation and comparison of data is difficult due to inconsistencies in sampling, concentration and recovery procedure. Landfill leachate and sewage sludge contained high numbers of potentially viable, human-virulent species of Cryptosporidium and Giardia. [25] Due to the massive amounts of sewage sludge used by agriculture or deposited in landfills [21,47-49] and the environmental robustness of these pathogens, [50-53] environmental contamination derived from landfill leachates and sewage sludge presents serious public and veterinary threats. For the sewage sludge-end products to be used without restriction on agricultural lands to grow readyto-eat crops, the pathogen load must be reduced to a level which does not pose acceptable public health or veterinary risks.[48,49]

\section{Conclusions}

Sludge treatments such as anaerobic and aerobic digestion, lime stabilization and heat drying do not eliminate Cryptosporidium oocysts and Giardia cysts.

Composting appears to be an interesting alternative to traditional disposal methods, since it is the only stabilization treatment which eliminates Giardia and Cryptosporidium (oo)cysts.

More information on the occurrence and levels of pathogens and indicators in biosolids is necessary to characterize and anticipate the risks associated with treated sewage sludge. An evaluation of the risks associated with the disposal or use of biosolids and proper regulations are both necessary from a public health perspective.

Further research is needed to establish whether treatment options could render the sewage sludge into pathogen-free biosolids, which can be safely disposed into the environment.

\section{Acknowledgements}

We thank two anonymous reviewers for their input which helped to clarify this paper. The authors would like to acknowledge the staff at WWTPs for providing the samples. 


\section{Disclosure statement}

No potential conflict of interest was reported by the author(s)

\section{References}

[1] Okhuysen PC, Chappell L, Crabb JH, et al. Virulence of three distinct Cryptosporidium parvum isolates for healthy adults. J Infect Dis. 1999;180:12751281.

[2] Medema GJ, Schijven JF. Modeling the sewage discharge and dispersion of Cryptosporidium and Giardia in surface water. Wat Res. 2001;35:4307-4316

[3] Slifko TR, Smith HV, Rose JB. Emerging parasite zoonoses associated with water and food .Int J Parasitol. 2000;30:1379-1393

[4] Thompson RCA. Giardiasis as re-emerging infectious disease and its zoonotic potential. Int J Parasitol. 2000;30:1259-1267

[5] Smith HV, Caccio SM, Cook N et al. Cryptosporidium and Giardia as foodborne zoonoses. Vet Parasitol. 2007;149: 29-40

[6] Ongerth JE. The concentration of Cryptosporidium and Giardia in water . The role and importance of recovery efficiency. Wat Res. 2013;47:2479 -2488.

[7] Ryan U, Caccio SM. Zoonotic potential of Giardia. Int J Parasitol. 2013;43:943956.

[8] Bicudo JR, Goyal SM. Pathogens and manure management systems: a review. Envirol Technol. 2003;24:115-130.

[9] Kim SB, Corapcioglu MY. Vertical Transport of Cryptosporidium parvum oocysts through sediments. Environ Technol. 2002;23:1435-1446.

[10] Amorós I, Alonso JL, Cuesta G. Cryptosporidium oocysts and Giardia cysts on salad products irrigated with contaminated water. J Food Prot. 2010;73:1138-1140.

[11] Liang Z, Keeley A. Detection of viable Cryptosporidium parvum in soil by reverse transcription-Real-Time PCR Targeting hsp70 mRNA. Appl Env Microbiol. 2011;77:6476-6485.

[12] Fayer R, Trout J, Jenkins MC. Infectivity of Cryptosporidium parvum oocysts in seawater and Eastern oysters (Crassostrea virginica) in the Chesapeake Bay. Appl Environ Microbiol. 1998;64:1070-1074.

[13] Godfree A, Farrell J. Processes for managing pathogens. J Environ Qual. 2005;34: 105-113. 
[14] Smith Jr JE, Surampalli RY, Reimers RS, et al. Disinfection processes and stability refinements to biosolids treatment technologies. Pract period hazard, toxic, radioact waste manag. 2008; 12: 10-17.

[15] Chauret C, Springthorpe S, Sattar S. Fate of Cryptosporidium oocysts, Giardia cysts, and microbial indicators during wastewater treatment and anaerobic sludge digestion. Can J Microbiol. 1999;45:257-262.

[16] Romdhana MH, Lecomte, D Ladevie B, et al. Monitoring of pathogenic microorganisms contamination during heat drying process of sewage sludge. Process Safety and Environ Protection. 2009;87:377-386.

[17] Sidhu JPS, Toze SG. Human pathogens and their indicators in biosolids: A literature review. Environ Int. 2009;35:187-201.

[18] Khouja LBA, Cama V, Xiao L. Parasitic contamination in wastewater and sludge samples in Tunisia using three different detection techniques. Parasitol Res. 2010;107:109-116.

[19] van Frankenhuyzen JK, Trevors JT, Lee H, et al. Molecular pathogen detection in biosolids with a focus on quantitative PCR using propidium monoazide for viable cell enumeration. J Microbiol Methods. 2011;87:263-272.

[20] Rimhanen-Finne R, Vourinen A, Marmo S, et al. Comparative analysis of Cryptosporidium and Giardia andindicator bacteria during sewage sludge hygienization in various composting processes. Lett Appl Microbiol. 2004;38:301305.

[21] Straub TM, Pepper IL, Gerba CP. Hazards from pathogenic microorganisms in land-disposed sewage sludge. Rev Environ Contam Toxicol. 1993;132:55-91.

[22] Schlosser O, Grall D, Laurenceau MN. Intestinal parasite carriage in workers exposed to sewage. Eur J Epidemiol. 1999;15:261-265.

[23] Nordic Council of Ministers, 2006 (C) Copenhagen. Protozoan Parasites in Sewage Sludge. TemaNord. 2006;596.

[24] Graczyk TK, Lucy FE, Tamang L, et al. Human enteropathogen load in activated sewage sludge and corresponding sewage sludge-end products. Appl. Environ Microbiol. 2007a;73:2013-2015.

[25] Graczyk TK, Kacprzak M, Neczaj E, et al. Occurrence of Cryptosporidium and Giardia in sewage sludge and solid waste landfill leachate and quantitative comparative analysis of sanitization treatments on pathogen inactivation. Environmental Res. 2008;106: 27-33.

[26] Guzmán C, Jofre J, Montemayor M, et al. Occurrence and levels of indicators and selected pathogens in different sludges and biosolids. J. Appl. Microbiol. 2007;103:2420-2429. 
[27] Cheng HW, Lucy FE, Graczyk TK, et al. Fate of Cryptosporidium parvum and Cryptosporidium hominis oocysts and Giardia duodenalis cysts during secondary wastewater treatments. Parasitol Res. 2009;105:689-696.

[28] Ashokkumar M,Vu T, Grieser F, et al. Ultrasonic treatment of Cryptosporidium oocysts. Water Sci Technol. 2003;47:173-177.

[29] Rimhanen-Finne R, Ronkainen P, Hanninen ML. Simultaneous detection of Cryptosporidium parvum and Giardia in sewage sludge by IC-PCR. J Appl Microbiol. 2001; 91: 1030-1035.

[30] Collins MV, Flick GJ, Smith S, et al. The effect of E-beam irradiation and microwave energy on Eastern oysters (Crasssostrea virginica) experimentally infected with Cryptosporidium parvum. J Eukaryot Microbiol. 2005;52:484-488.

[31] Santos LU, Bonatti TR, Cantusio R, et al. Occurrence of Giardia cysts and Cryptosporidium oocysts in activated sludge samples in Campinas, SP, Brazil. Rev Inst Med S Paulo. 2004;46:309-313.

[32] Bukhari Z, Smith HV, Sykes N, et al. Occurrence of Cryptosporidium spp. oocysts and Giardia spp. cysts in sewage effluents and effluents from treatment plants in England. Water Sci Technol. 1997;35:385-390.

[33] Kuczynska E, Shelton DR. Method for detection and enumeration of Cryptosporidium parvum oocysts in feces, manures and soils. Appl Environ Microbiol. 1999;65:2820-2826.

[34] U.S. Environmental Protection Agency (USEPA). Method 1623: Cryptosporidium and Giardia in water by IFA/IMS/FA. EPA 815-R-05-002. Washington, DC, USA: Office of Water, United States Environmental Protection Agency; 2005.

[35] Iacovski RB, Barardi CRM, Oliveira CM. Detection and enumeration of Cryptosporidium sp. oocysts in sewage sludge samples from the city of Florianópolis (Brazil) by using immunomagnetic separation combined with indirect immunofluorescence assay. Waste Manage Res. 2004;22:171-176.

[36] Orlofsky E, Gillor O, Melli A, et al. Simultaneous detection of Giardia lamblia and Cryptosporidium parvum (oo)cysts in soil using immunomagnetic separation and direct fluorescent antibody staining .J Microbiol Methods. 2013;94:375-377.

[37] Massanet-Nicolau J. New Method Using Sedimentation and Immunomagnetic Separation for Isolation and Enumeration of Cryptosporidium parvum Oocysts and Giardia lamblia cysts. Appl Environ Microbiol. 2003;69:6758-6761.

[38] Feachem RG, Bradley DJ, Garlick H, et al. Sanitation and Disease: Health Aspects of Excreta and Wastewater Management. 1983 New York, NY: John Wiley and Sons. 
[39] Wichuk KM, McCartney D. A review of the effectiveness of current time temperature regulations on pathogen inactivation during composting. Journal of Environmental Engineering Science. 2007;6:573-586.

[40] Hu CJ, Gibbs RA, Mort NR, et al. Giardia and its implications for sludge disposal. Water Sci Technol. 1996;34:179-186.

[41] Soares AC, Straub TM, Pepper IL, et al. Effect of anaerobic digestion on the occurrence of enteroviruses and Giardia cysts in sewage sludge. J Environ Sci Health. 1994;29:1887-97.

[42] Sykora JL, Sorber CA, Jakubowski W, et al. Distribution of Giardia cysts in wastewater. Wat Sci. Tech. 1991; 24:187-192.

[43] Marín I, Goñi P, Lasheras AM, et al. Efficiency of a Spanish wastewater treatment plant for removal potentially pathogens: Characterization of bacteria and protozoa along water and sludge treatment lines. Ecol Eng. 2014; 74:28-32.

[44] Robertson LJ, Paton CA, Campbell AT, et al. Giardia cysts and Cryptosporidium oocysts at sewage treatment works in Scotland, UK. Water Res. 2000;34:23102322.

[45] Payment P, Plante R, Cejka P. Removal of indicator bacteria, human enteric viruses, Giardia cysts, and Cryptosporidium oocysts at a large wastewater primary treatment facility. Can J Microbiol. 2001;47:188-93.

[46] Caccio SM, De Giacomo M, Aucilino FA, et al. 2003. Giardia cysts in wastewater treatment plants in Italy. Appl Environ Microbiol. 2003;69:3393-3398.

[47] Szostakowska B, Kruminis-Lozowska W, Racewicz M, et al. Cryptosporidium parvum and Giardia lamblia recovered from flies on a cattle farm and in a landfill. Appl Environ Microbiol. 2004;70:3742-3744.

[48] Westrell T, Schonning C, Stenstrom TA, et al. QMRA (quantitative microbial risk assessment) and HACCP (hazard analysis and critical control points) for management of pathogens in wastewater and sewage sludge treatment and reuse. Water Sci Technol. 2004;50:23-30.

[49] Gale P. Land application of treated sewage sludge: quantifying pathogen risk from consumption of crops. J Appl Microbiol. 2005;98:380-396.

[50] deRegnier DP, Cole L, Schupp DG, et al. Viability of Giardia cysts suspended in lake, river, and tap water. Appl Environ Microbiol. 1989;55:122-129.

[51] Tamburrini A, Pozio E. Long-term survival of Cryptosporidium parvum oocysts in seawater and in experimentally infected mussels (Mytilus galloprovincialis). Int J Parasitol. 1999;29:711-715. 
[52] Hutchinson ML, Walters LD, Moore T, et al. Fate of pathogens present in livestock wastes spread onto fescue plots. Appl Environ Microbiol. 2005a;71:691-696.

[53] Hutchinson ML, Walters LD, Moore T, et al. Decline of zoonotic agents in liquid livestock wastes stored in batches on-farm. Lett Appl Microbiol. 2005b;99:58-65. 
Table 1: Characteristics of wastewater treatment plants: population served and different sludge treatments

\begin{tabular}{|c|c|c|c|c|}
\hline $\begin{array}{l}\text { Wastewater } \\
\text { Treatment } \\
\text { Plant }\end{array}$ & $\begin{array}{l}\text { Population } \\
\text { equivalent }\end{array}$ & $\begin{array}{l}\text { Secondary } \\
\text { treatment }\end{array}$ & $\begin{array}{l}\text { Tertiary } \\
\text { treatment }\end{array}$ & $\begin{array}{l}\text { Sludge } \\
\text { Treatment }\end{array}$ \\
\hline WWTP1 & 205650 & $\begin{array}{c}\text { Activated } \\
\text { sludge and } \\
\text { sedimentation }\end{array}$ & $\begin{array}{c}\text { Sand } \\
\text { filtration, } \\
\text { ultraviolet }\end{array}$ & $\begin{array}{l}\text { Anaerobic } \\
\text { Digestion }\end{array}$ \\
\hline WWTP2 & 49702 & $\begin{array}{c}\text { Activated } \\
\text { sludge and } \\
\text { sedimentation }\end{array}$ & None & $\begin{array}{c}\text { Aerobic } \\
\text { Digestion }\end{array}$ \\
\hline WWTP3 & 21255 & $\begin{array}{c}\text { Activated } \\
\text { sludge and } \\
\text { sedimentation }\end{array}$ & $\begin{array}{l}\text { Sand } \\
\text { filtration, } \\
\text { ultraviolet }\end{array}$ & $\begin{array}{c}\text { Lime } \\
\text { stabilization }\end{array}$ \\
\hline WWTP4 & 20055 & $\begin{array}{c}\text { Activated } \\
\text { sludge and } \\
\text { sedimentation }\end{array}$ & None & $\begin{array}{c}\text { Aerobic } \\
\text { Digestion }\end{array}$ \\
\hline WWTP5 & 20092 & $\begin{array}{c}\text { Activated } \\
\text { sludge and } \\
\text { sedimentation }\end{array}$ & Ultraviolet & $\begin{array}{l}\text { Lime } \\
\text { stabilization } \\
\text { and heat } \\
\text { drying }\end{array}$ \\
\hline $\mathrm{CP}^{\mathrm{a}}$ & - & - & - & Composting \\
\hline
\end{tabular}

${ }^{\mathrm{a}}$ Composting plant 
1 Table 2: Cryptosporidium oocysts and Giardia cysts in raw and treated sludge

\begin{tabular}{|c|c|c|c|c|c|c|c|c|c|c|c|c|c|c|c|c|c|c|c|c|c|c|c|c|}
\hline \multirow[b]{3}{*}{ Sampling } & \multicolumn{4}{|c|}{ WTP 1} & \multicolumn{4}{|c|}{ WTP 2} & \multicolumn{4}{|c|}{ WTP 3} & \multicolumn{4}{|c|}{ WTP 4} & \multicolumn{4}{|c|}{ WTP 5} & \multicolumn{4}{|c|}{$\mathrm{CP}$} \\
\hline & \multicolumn{2}{|c|}{ Oocysts/g } & \multicolumn{2}{|c|}{ Cysts/g } & \multicolumn{2}{|c|}{ Oocysts/g } & \multicolumn{2}{|c|}{ Cysts/g } & \multicolumn{2}{|c|}{ Oocysts/g } & \multicolumn{2}{|c|}{ Cysts/g } & \multicolumn{2}{|c|}{ Oocysts/g } & \multicolumn{2}{|c|}{ Cysts/g } & \multicolumn{2}{|c|}{ Oocysts/g } & \multicolumn{2}{|c|}{ Cysts/g } & \multicolumn{2}{|c|}{ Oocysts/g } & \multicolumn{2}{|c|}{ Cysts/g } \\
\hline & $\begin{array}{c}\text { raw } \\
\text { sludge }\end{array}$ & $\begin{array}{l}\text { treated } \\
\text { sludge }\end{array}$ & $\begin{array}{c}\text { raw } \\
\text { sludge }\end{array}$ & $\begin{array}{l}\text { treated } \\
\text { sludge }\end{array}$ & $\begin{array}{c}\text { raw } \\
\text { sludge }\end{array}$ & $\begin{array}{l}\text { treated } \\
\text { sludge }\end{array}$ & $\begin{array}{l}\text { raw } \\
\text { sludge }\end{array}$ & $\begin{array}{l}\text { treated } \\
\text { sludge }\end{array}$ & $\begin{array}{c}\text { raw } \\
\text { sludge }\end{array}$ & $\begin{array}{l}\text { treated } \\
\text { sludge }\end{array}$ & $\begin{array}{c}\text { raw } \\
\text { sludge }\end{array}$ & $\begin{array}{l}\text { treated } \\
\text { sludge }\end{array}$ & $\begin{array}{c}\text { raw } \\
\text { sludge }\end{array}$ & $\begin{array}{l}\text { treated } \\
\text { sludge }\end{array}$ & $\begin{array}{c}\text { raw } \\
\text { sludge }\end{array}$ & $\begin{array}{l}\text { treated } \\
\text { sludge }\end{array}$ & $\begin{array}{c}\text { raw } \\
\text { sludge }\end{array}$ & $\begin{array}{l}\text { treated } \\
\text { sludge }\end{array}$ & $\begin{array}{c}\text { raw } \\
\text { sludge }\end{array}$ & $\begin{array}{l}\text { treated } \\
\text { sludge }\end{array}$ & $\begin{array}{c}\text { raw } \\
\text { sludge }\end{array}$ & $\begin{array}{l}\text { treated } \\
\text { sludge }\end{array}$ & $\begin{array}{c}\text { raw } \\
\text { sludge }\end{array}$ & $\begin{array}{l}\text { treated } \\
\text { sludge }\end{array}$ \\
\hline 1 & 354 & 498 & 124 & 248 & 21 & 69 & 4 & 4 & 268 & 48 & 85 & 75 & 0 & 55 & 0 & 8 & 0 & 5 & 0 & 1 & 14 & 0 & 1 & 0 \\
\hline 2 & 140 & 87 & 174 & 83 & 13 & 24 & 3 & 1 & 164 & 125 & 74 & 93 & 0 & 21 & 1 & 31 & 0 & 8 & 1 & 24 & 51 & 0 & 71 & 0 \\
\hline 3 & 325 & 173 & 213 & 182 & 18 & 18 & 9 & 20 & 171 & 79 & 171 & 27 & 11 & 19 & 6 & 36 & 12 & 8 & 4 & 27 & 48 & 0 & 98 & 0 \\
\hline 4 & 126 & 104 & 97 & 48 & 2 & 8 & 3 & 3 & 39 & 48 & 30 & 76 & 7 & 25 & 1 & 14 & 5 & 5 & 18 & 58 & 27 & 0 & 63 & 0 \\
\hline 5 & 59 & 100 & 77 & 100 & 2 & 7 & 2 & 1 & 52 & 17 & 155 & 13 & 5 & 12 & 0 & 22 & 6 & 7 & 0 & 2 & 22 & 0 & 64 & 0 \\
\hline Average & 201 & 192 & 137 & 132 & 11 & 25 & 4 & 6 & 139 & 63 & 103 & 57 & 5 & 26 & 2 & 22 & 5 & 7 & 5 & 22 & 32 & 0 & 59 & 0 \\
\hline SD & 131 & 174 & 56 & 81 & 9 & 25 & 3 & 8 & 95 & 41 & 59 & 35 & 5 & 17 & 3 & 12 & 5 & 2 & 8 & 23 & 16 & 0 & 36 & 0 \\
\hline *uncertainty & 59 & 78 & 25 & 36 & 4 & 11 & 1 & 4 & 42 & 18 & 26 & 16 & 2 & 8 & 1 & 5 & 2 & 1 & 4 & 10 & 7 & 0 & 16 & 0 \\
\hline
\end{tabular}

*SD/total sampling 